\title{
Two Perceptions of Change in Judeo-Spanish Rabbinic Literature
}

\author{
Matthias B. LEHMANN
}

CSIC, Madrid

Since all human experience is situated in time and space, the metamorphoses of their representations provide a convenient framework for studying the construction and transformation of societies and cultures ${ }^{1}$. Indeed, Anthony Giddens included the disengagement of the relation between time and space and the subsequent «disembedding» of social systems among the four basic processes which constitute modernity ${ }^{2}$.

The conquering of space in the era of the nation state, new techniques of transportation and political, economic, and cultural imperialism; the increasing pace of communication through new media like the telegraph and the sense of simultaneity; the shortening of distances regionally and world wide: all profoundly transformed the space of experience and the horizon of expectation in the different cultures affected by these developments.

Whether the shortening of distances was real or imagined, whether the changes really affected the daily life of broad seg-

\footnotetext{
${ }^{1}$ The transcription of the cited Judeo-Spanish texts follows the system adopted by Sefarad; proper names and book titles have been transcribed within the English text, however, according to a simplified system more intelligible to the English reader. I wish to thank those who read and commented on earlier versions of this paper: Professor Esther Benbassa (CNRS, Sorbonne, Paris), Dr. Javier Castaño (Universidad Complutense, Madrid), and Dr. Elena Romero (CSIC, Madrid). Dr. Iacob M. Hassán (CSIC), "véritable encyclopédie du sépharadisme» laboriously read the final draft and corrected the transcriptions. I am especially indebted to Professor Peter Schäfer (Freie Universität Berlin and Princeton University) for his support of my research. I am very grateful to Julie L. Scolnik (Madrid) who corrected my English.

${ }^{2}$ Anthony Giddens, Consequences of Modernity (Stanford 1990).
} 
ments of society or rather a few privileged sectors like international trade and banking is not at stake here ${ }^{3}$. The notion of a communication revolution, however, forms part of a more general process culminating at the turn of the nineteenth century: «From around 1880 to the outbreak of World War I, a series of sweeping changes in technology and culture created distinctive modes of thinking about and experiencing time and space ${ }^{4} \gg$.

Building on a close reading of two references to the invention of the telegraph in the Ottoman Empire found in two Judeo-Spanish ethical treatises, this study tries to look at some general lines of perceptions of change as a manifestation of different understandings of time. We shall leave aside perceptions of space, the constructions and deconstructions of notions like home and diaspora, centre and periphery, etc., and focus on the present time understood as the difference of past and present and the notion of change (or nonchange) generated by this difference 5 .

Especially in times of transition, when hitherto unchallenged cultural universes undergo transformation from within or without, the patterns of representation of time provide much insight into how people succeed in assimilating change, which mechanisms they employ to ward off change or, by way of contrast, how they join in the process of producing change. This is true, I argue, for the study of the transformation of Sephardic society and culture in the nineteenth century as well.

Unlike the impact of bureaucratic reforms ${ }^{6}$ and the establishment

${ }^{3}$ On the effects of the nineteenth century «communication revolution» see Michael NoTH (ed.), Kommunikationsrevolutionen: Die neuen Medien des 16. und 19. Jahrhunderts (Vienna 1995).

${ }^{4}$ Stephen KERN, The Culture of Time and Space, 1880-1918 (Cambridge, Mass., 1983) p. 1.

${ }^{5}$ For a definition of time, we follow Niklas Lummann, Soziale Systeme: Grundriß einer allgemeinen Theorie (Frankfurt $1999^{7}$ [1984]) pp. 377-487, and «The Future Cannot Begin: Temporal Structures in Modern Society», Social Research 43 (1976) pp. 130-152; furthermore the relevant entries in Claudio BARALDI, Giancarlo CORSI and Elena Esposito (eds.), GLU: Glossario dei termini della teoria dei sistemi di Niklas Luhmann (Urbino 1989).

${ }^{6}$ Cf. Şerif MARDIN s.v. «Tanzimat», and Gudrun KRÄMER s.v. «Minorities in Muslim Societies», in Encyclopaedia of the Modern Islamic World, ed. John L. ESPOSITO (Oxford 1995); Paul DUMONT, «La période des Tanzîmât (1839-1878)», in Histoire de l'Empire Ottoman, ed. Robert MANTRAN (Paris 1989) pp. 459-522; Donald QUATAERT, «The Age of Reforms, 1812-1914», in An Economic and Social History of the Ottoman Empire, ed. Halil INALCIK (with Donald QuATAERT) 
of new educational networks (e.g. the Alliance Israélite Universelle ${ }^{7}$ ) on the Ottoman-Sephardic society, reactions to the revolution of communication and transport ${ }^{8}$ have not been studied in much detail ${ }^{9}$. Neither has research focused on changing representations of time or perceptions of change -a subject which might contribute to our understanding of the profound transformation which Sephardic societies underwent in the period ${ }^{10}$.

In the present study, we shall examine two approaches to time and change in rabbinic ethical literature written in Judeo-Spanish in the nineteenth century Ottoman Empire. In a first step, we are going to look at the daring interpretation given to the communication revolution by Yeuda Papo in his Ladino version of the Pele $Y o$ 'ets which had originally been written by his father Eli'ezer in Hebrew ${ }^{11}$. Secondly, there is a brief, but telling reference to the telegraph in Binyamin Ben-Tsion Rodeti's Sefer Ki Ze Kol haAdam ${ }^{12}$. Finally, these two references to the telegraph shall be set in a larger perspective of the envisioning of change in JudeoSpanish rabbinic ethical literature.

\section{Some Methodological Considerations}

First of all, it is necessary to ask what insights into social and cultural change can be expected from a study of rabbinic litera-

(Cambridge 1994) pp. 759-943; the classic by Roderic F. DAVISON, Reform in the Ottoman Empire, 1856-1876 (New York 1973) and Carter V. FindLEY, Bureaucratic Reform in the Ottoman Empire: The Sublime Porte, 1789-1922 (Princeton 1980); Suraiya FAROQHI, Kultur und Alltag im Osmanischen Reich (Munich 1995).

${ }^{7}$ Cf. Aron Rodrigue, French Jews, Turkish Jews (Bloomington 1990).

${ }^{8}$ Cf. QuATAERT «The Age», on transportation, pp. 798-823; Paul DumonT and François GeORgEON (eds.), Villes ottomanes à la fin de l'empire (Paris 1992).

${ }^{9}$ The major exception to the rule, though not for Judeo-Spanish literature, is Zvi ZOHAR, Tradition and Change: Halakhic Responses of Middle Eastern Rabbis to Legal and Technological Change (Egypt and Syria, 1880-1920) (Jerusalem 1993) (Hebrew).

${ }^{10}$ Forthcoming is, however, a study of the perceptions of time in German Jewry by Jacques Ehrenfreund.

${ }^{11}$ First Ladino version, 2 vols., Vienna 1870/71; second edition Salonica 1899/1900. Cf. Elena RoMERo, La creación literaria en lengua sefardí (Madrid 1992) pp. 114-116. I use the copy in the Library for Sephardic Studies of the CSIC, Madrid (second edition; henceforth cited as $P Y$ )

${ }^{12}$ Izmir 1884. Cf. Romero Creación p. 114. I use the copy at the CSIC library (henceforth cited as $K A$ ). 
ture. Historians of premodern and modern Judaism have made use of rabbinic, mostly legal, literature, the most notable example being of course the pioneering work of the late Jacob Katz on the transformation of Central and Eastern European Judaism ${ }^{13}$. A less obvious source (though Katz made use of it as well) is the rabbinic ethical, rather than legal, the musar literature, which David Sorkin has used to argue for an «early haskala» preparing the way of German Jewry's way into modernity ${ }^{14}$.

While legal literature lends itself much easier to a sociohistorical analysis, discussing as it does the application of legal norms in concrete circumstances, musar literature might disappoint the historian in search of things «new», in search of change. Ethical treatises usually present themselves as rather conservative and therefore call for a very close reading if we wish to learn about the author relating himself to developments occurring in the society in which he lives. Notwithstanding their conservative attire, however, musar literature has served throughout Jewish history precisely for the integration of new modes of thought into the mainstream of Judaism. This observation presented by Joseph Dan holds true, as I shall argue, for the JudeoSpanish ethical literature of the nineteenth century as well ${ }^{15}$. Jewish ethics, as Joseph Dan has it, was a

force that absorbed the revolutionary new ideas of philosophers, pietists, and mystics and turned them into a constructive and

13 Jacob KATZ, Tradition and Crisis: Jewish Society at the End of the Middle Ages (New York 1993) and KATZ' collected essays in Halakha ve-qabbala: Mehqarim betoledot dat Yisrael 'al medoreha ve-ziqatah ha-hevratit (Jerusalem 1984); for the Ottoman context, cf. the works by Joseph R. HACKER, «Jewish Autonomy in the Ottoman Empire: Its Scope and Limits. Jewish Courts from the Sixteenth to the Eighteenth Centuries», in The Jews of the Ottoman Empire, ed. Avidgor LEVY (Princeton 1994) pp. 153-202; "The Sürgün System and Jewish Society in the Ottoman Empire during the Fifteenth to the Seventeenth Centuries", in Ottoman and Turkish Jewry: Community and Leadership, ed. Aron RODRIGUE (Bloomington 1992) pp. 1-65. Another case of historic analysis on the basis of halakhic literature is Aryeh SHMUELEVITZ, The Jews of the Ottoman Empire in the Late Fifteenth and the Sixteenth Centuries: Administrative, Economic, Legal and Social Relations as Reflected in the Responsa (Leiden 1984).

14 David Sorkin, The Transformation of German Jewry, 1780-1840 (Detroit $1999^{2}$ ) pp. 45-53; Azriel SHOHET, Im hilufe tequfot (Jerusalem 1960).

15 Joseph DAN, Jewish Mysticism and Jewish Ethics (Seattle 1986) pp. 1-14 and passim; the following quotation is on p. 104. 
conservative ideology ... the thesis should be presented that, as far as traditional, orthodox Judaism is concerned, what was true in the Middle Ages is even more so in the period starting in the seventeenth century. The role of ethical literature, especially mystical ethics, only increased during these centuries.

The integration of new ideas into the traditional universe belongs, then, to the very functions of ethical literature. A close reading of how individual musar authors relate their own time to past and future can hereby, as we shall see, serve as an indicator of how external change was integrated into the traditional universe. As one scholar recently defined it,

«Modernity» signifies the historical epoch in which, for an increasing majority of inhabitants in Europe and then other parts of the globe, an asymmetry between «hope» and «memory,» or between the «horizon of expectation» and the «space of experience," becomes the fundamental condition of societal relationships. Experience is "present past, whose events have been incorporated and can be remembered,» whereas expectation is «the future made present» that «directs itself to the not-yet.» Before modernity, hope and memory worked in a rough balance. But after the seventeenth century, and then more forcefully after the French Revolution, industrialization, and the rise of territorial nation-states, hope disengaged from memory. Anticipation of the future worked without deferring primarily to the authority of remembrance. «Progress» came to signify this twin movement of an optimistic opening toward a future relatively unbounded by experiential factors ... ${ }^{16}$.

For Jewish perceptions of history, too, memory and hope were intimately related in the traditional universe, the biblical past being understood as an archetypical prefiguration of what was to be the messianic future. Nothing really new and different was to be expected from the immediate future, the territory of expectation cleary being mapped out by the biblical narrative and its

${ }^{16}$ Rudy KosHaR, Germany's Transient Pasts: Preservation and National Memory in the Twentieth Century (Chapel Hill 1998) p. 18, using the concepts of «space of experience» and «horizon of expectation» as developed by Reinhart KOSELLECK, "Erfahrungsraum" und "Erwartungshorizont"-zwei historische Kategorien», in Vergangene Zukunft: Zur Semantik geschichtlicher Zeiten (Frankfurt 199533 [1979]) pp. 349-375, and other essays assembled there; for an English translation, Reinhart Koselleck, Futures Past: On the Semantics of Historical Time, tr. Keith TRIBE (Cambridge, Mass., 1985). 
interpretative tradition ${ }^{17}$. In this view, things obviously «happened», but they did not produce change in any significant sense and were not permitted to transform the patterns of the traditional universe. The openness of future would clearly be a result of the modern condition ${ }^{18}$.

As shall become clear in this study, at least two different trends can be distinguished in the Judeo-Spanish rabbinic ethical literature, each coming to terms with social, cultural, and technological change in a different way. While Rodeti perpetuates the traditional vision and denies change, reading the present and future expectations through the biblical past, Papo does not only recognize change but even interprets it as progress.

We will not consider here legal or "pragmatic» responses to technological change. To take up the example which we will be considering in greater detail, the invention of the telegraph, in the Pele Yo ets we find one reference where the author encourages traders not to invest all their capital in one product because of the risks involved, and not to store large quantities of one article and tells his readers: «Y que no se asufra sobre su ešpeculación, que él la ordena con vapor y con telegraf y le viene a él antes de otros» ${ }^{19}$. In our present discussion, we shall turn to new representations of time caused by such technological inventions as well as cultural changes ${ }^{20}$.

17 The most significant contributions to the study of Jewish historical consciousness in recent years are: Yosef Hayim YERUSHALMI, Zakhor: Jewish History and Jewish Memory (Seattle 1982), and Amos FUNKENSTEIN, Perceptions of Jewish History (Berkeley - Los Angeles 1993).

18 LUHMANN «The Future» p. 131.

${ }^{19}$ PY 2:107: 'He should not trust his own speculation, because he orders [the merchandise] by steam ship and telegraph and it will reach him earlier than it will others'.

${ }^{20}$ For the «modernization» or «Westernization» of Sephardic societies, cf. Esther BENBASSA, "Processus de modernisation en terre sépharade», in La société juive à travers l'histoire, ed. Shmuel TRIGANO (Paris 1992) vol. I pp. 565-605; Joseph CHETRIT, «Discours et modernité dans les communautés juives d'Afrique du Nord à la fin du XIXe siècle», in Transmission et passages en monde juif, ed. Esther BENBAsSA (Paris 1997) pp. 379-400; Harvey E. GoldBERG, «Religious Responses Among North African Jews in the Nineteenth and Twentieth Centuries", in The Uses of Tradition: Jewish Continuity in the Modern Era, ed. Jack WERTHEIMER (New York 1992) pp. 119-144; Aron RoDRIGUE, «The Beginnings of Westernization and Community Reform Among Istanbul's Jewry, 1854-65», in The Jews of the Ottoman Empire, ed. Avigdor LEVY (Princeton 1994) pp. 439-456; Norman A. Stillman, Sephardi Religious Responses to Modernity (Luxembourg 1995). 


\section{THE RAPPROCHEMENT OF RELIGIONS}

The chapters of the Pele Yo ets are arranged alphabetically and present an organization of knowledge worth a separate discussion for itself ${ }^{21}$. Under the title «ge'ula» ('redemption'), we find a fascinating and surprising interpretation of the revolutionizing of communication in the Ottoman Empire in the nineteenth century:

Al pricipio el 'olam era muy lejos de parte a parte en viaje de mar. En tiempo antigo se espantaban de caminar por golfos, caminaban todos a oría de la mar y se les alargaba mucho los viajes. Salieron las cencias de viajar todo por los golfos y se les acortó los caminos y mancos rísicos. Salió después las hojmot de los vapores que se arodea el 'olam entero en poco tiempo. Por tiera salió la caroza de fuego que arodea el 'olam entero en pocos días. Salió el telégrafo que arodea el 'olam entero en pocas horas. Se entiende que el ruhaniyut es ansí y es el acercamiento de las emunot según la cośa ya empezó a amostrar punta [...].

Mośotros no puede ser que manquemos de muestra Ley, que ansí estamos encomendados que dijo el pasuc: Veló tigre ú mimenu [Dt $4: 2]$. Las naciones no tienen hiyub de recibir muestra Ley, que lo que se en ${ }^{151}$ comendaron es en las siete miŝvot que se encomendó Nóah y ya las afirman. Dunque el acercamiento de las emunot tiene que ser en lo que las naciones cada veź van haćiendo más dikat en la quedušá de muestra Ley y en la quedušá de Yisrael [...]. Y cuanto más va pujando esto, puede venir dérej teba' que se haga aunamiento en los maljuyot y que lo topen de justo de dar todas las fuerzas a la umá yisraelit por que tengan sus tieras y podestanía. Y afilú esto no puede venir si no con que lo merecemos ${ }^{22}$.

${ }^{21}$ I discuss this issue in a forthcoming article on «Representations and Transformation of Knowledge in the Judeo-Spanish Ethical Literature». The organization according to subject matter in alphabetic order itself is not new but follows the model established by Bahya ben Ašer from thirteenth century Saragossa in his Kad ha-Qemah, published in Kitve rabbenu Bahya, ed. Hayim Dov SHEvel (Jerusalem 1970) pp. 17-451.

${ }_{22} P Y$ 1:150-151: 'In the beginning, the different parts of the world were a long voyage's distance from one another. In ancient times, one feared to travel by crossing the open sea, [people] travelled close to the seashore, and travelling took a lot of time. Then the sciences of navigation were invented, [making it possible] to travel by crossing the open sea and the routes became shorter and less risky. Subsequently, the science of the steam ship was invented and the entire world could be encompassed in a short time. On the mainland, the railway was invented and encompasses the world in a few days. The telegraph was invented and encompasses the entire world in a few hours. It is clear that spiritually it is the 
In this passage, Papo gives the technological innovations of his time a meaning which makes use of traditional imagery but, at the same time, goes far beyond it. The «disembedment» of time and space, the world becoming «smaller» and its different parts getting closer to one another are seen as reflecting a development in the history of religions: they, too, come nearer one to another. Or, to be more precise: Presenting a counter-model to Jewish assimilation to others, namely to European ways of life which were invading the cities of the Ottoman Empire in the nineteenth century, Papo claims that the non-Jews have, with the passing of the ages, come nearer to the ideals of Judaism. They increasingly respect the holiness of Israel and the authority of their Law and of the rabbis.

Such an optimistic reading of history can be found throughout many different passages in the Pele Yo ets. To Papo, if the exile has become easier to bear, it is because the ideals of Judaism have spread across the world ${ }^{23}$. Here, however, Papo gives his argu

same, that is, the faiths approach one another, which has already begun to show its point $[. .$.$] . We [however] should not substract anything from our Law which we$ have been commanded, as it is said: [You shall not add to the word that I command you], nor shall you substract from it. The gentiles are not obliged to receive our Law, because it is the seven commandments of Noah [and nothing more] which they have been commanded, and they already do affirm these. Therefore the coming closer of faiths must occur by the gentiles becoming more and more aware of the holiness of our Law and the holiness of Israel [...]. And as this progresses, it may come by way of nature [«be-derekh teva'», and not miraculously] that the kingdoms unite and find it right to confer all the [political] powers to the Jewish people so that they may have their land and dominion over it. But even this cannot happen if we do not deserve it'.

${ }^{23}$ Cf. PY 1:139f: «El galut se alivianó del rob de las partes del 'olam y la raźón es con el dicho que dićen hajamim que no hay enemistad en el mundo como la enemistad de la Ley. Que en tiempo antiguo la enemistad de la Ley estaba cavacada en los corazones de las naciones sobre la umá yisraelit. Esto cavśaba el galut fuerte y los šemadot y los guerušim teribles que pasaron en la umá yisraelit. $Y$ agora que se van muchiguando las cencias y se va acercando el $1140^{*}$ olam al punto de la verdad, ya están aĉetados todas las naciones que muestra Ley es santa y dada a mośotros en monte de Sinay y que la nación yisraelit es el pueblo escoǵido del Criador, nada no hay encubierto de ellos. En tiempos antiguos todas las naciones servían ídolos y haćían muchas cośas negras, feas y estrañas. Ellos propios se fueron ale jando de sus caminos y se fueron acercando a muestra Ley, de conocer que hay Dio en los cielos y cuantas cośas buenas que hay en muestra Ley". "The diaspora has become easier to bear in most parts of the world and it is right what the sages said that there is no hatred in the world like the hatred of the Law. In ancient times, the hatred of the Law was engraved in the hearts of the nations 
ment another, surprising turn: If the gentiles increasingly appreciate the ideals of Judaism and if the Jews remain faithful to their tradition, even a restoration of Israel to her promised land could be the result. He thus invents a counter-myth on the impact of modernity opposed to the Western European model, re-reading modernity and emancipation as others approaching Judaism and thus reaffirming rabbinic tradition rather than challenging it.

The text cited above indicates that Yeuda Papo, who added this reference to the telegraph to his father's book ${ }^{24}$, had an awareness of change in the world he lived in. It can even be argued that the representation of technological innovations is only one example for his vision of a broader process of change which makes his own time different from earlier times: Other aspects include his comments on the educational work of the Alliance Israélite Universelle (active since the 1860s) ${ }^{25}$ or the impact of the expansion of Hebrew printing in the Empire ${ }^{26}$-both notably representing new modes of communication, i. e., a modern school network, the spread of printed texts among a broad, non-specialized public, and the press.

All this certainly is far from a revolutionary redrawing of the traditional universe. Papo actually employs here elements from earlier Jewish readings of history (which is not surprising given the quotational character of rabbinic tradition, its «zitathaftes Leben», to use Thomas Mann's phrase which Michael Fishbane applied to rabbinic literature ${ }^{27}$ ).

against the Jewish people. This caused the hardship of diaspora, the persecutions and the awful expulsions which came to pass to the Jewish people. Now, that knowledge multiplies and the world is approaching to the moment of truth, the nations consent that our Law is holy, and was given to us on Mount Sinai, and that the Jewish people are the people chosen by the Creator, nothing being hidden from them. In ancient times, all the nations served idols and committed many bad, evil and strange things. They themselves moved away from their [evil] ways and came closer to our Law, to recognize that there is [one] God in the heavens and so many good things that are in our Law'.

${ }^{24}$ In the introduction to the chapter «Mitsvot» (PY 2:116), Yeuda Papo explains how he has transformed -added to, changed, and substracted from- his father's Hebrew work.

${ }^{25} P Y 2: 203$

${ }^{26} P Y 1: 205 \mathrm{f}$.

${ }^{27}$ Michael Fishbane, The Exegetical Imagination: On Jewish Thought and Theology (Cambridge, Mass., 1998)' p. 1. 
To remain in the Ottoman context, consider for example Eliyahu Capsali's historiographical account of the Ottoman conquests in the Near East which he gave a messianic meaning as a step towards redemption ${ }^{28}$. What seems significant here is that Papo recognized one of the major processes of the emerging modern society -the communication revolution of the nineteenth century, the «disembedment» of time and space- as something positive and gives it a religious meaning as harbinger of redemption.

But let us return to the brief passage cited above. The text contains more than a superficial reading suggests. Technological change is seen as a metaphor for a development on the spiritual level, the approximation of religions. Papo states that such an approximation should not take on the form of the Jews acculturating to others but, quite to the contrary, to remain true to their own tradition and to wait for these others to come nearer to the ideals of Judaism.

He thereby argues that those who call for an acculturation of Jewish tradition to the patterns set by nineteenth century European culture are quite wrong in their understanding of the changes occurring around them. The Jews have to remain faithful to the old ways more than ever precisely because their mission in the world has been so successful and has to be carried on.

This argument reminds us of West European maskilim who wished to give religious legitimation to Jewish emancipation in the modern nation states while refuting assimilation by insisting on the «monotheistic mission» of Judaism ${ }^{29}$.

This interpretation of change is a polemic response against some "others» labelled "apicorosim" (utilizing the rabbinic term for practically anyone expressing diverging ideas ${ }^{30}$ ) or «philosophers», against the Westernizers among the Sephardim who see the changes as a challenge calling for imitating the European nations:

[...] se topan alguna ĝente que los sonbaye el yéŝer hará y les diće que en muestros tienpos se muchiguaron las cencias en el

\footnotetext{
${ }^{28}$ Eliyahu CAPSAli, Seder Eliyahu Zuta, ed. Aryeh ShMUELEvitz, Shlomo SiMONSOHN and Meir BENAYAHU, 2 vols. (Jerusalem-Tel Aviv 1975, 1977) book III: vol. I pp. 265-409.

${ }^{29}$ SORKIN Transformation pp. $103 \mathrm{f}$.

${ }^{30}$ Encyclopaedia Judaica s.v. «Apikoros».
} 
mundo más que los dorot antigos, y cada uno cale que ešpeculee a entender y saber las cośas con su meollo y no con meollo de otros. Y más que les parece que el cumplimiento de mośotros cale que sea con hacer igualanza con las naciones, asemejarmos a ellos en todo modo de cośa afilú si por cavśa de esto es menester de mancar alguna cośa de la Ley y cuánto y más si es cośa de hajamim. Y más que meten temel en sus meollos que no hay cośa que sale de la natura y todo lo que les ${ }^{166}$ viene afuera del meollo y de la natura no dan crédito en ello. Que esto les viene por meldar libros de filosofim que en el meollo de ellos es que no hay cośa afuera de la natura.

Según de todo lo que dijimos y se declaró muy bien, la Ley y las miŝvot son de lugar muy alto y santo más ariba de la natura, que ansí se topa en ella cuantas cośas que vienen contra el meollo y la natura y mośotros jidiós tenemos obligo de atorgar en ellas. Y los que tienen en sus meollos que non hay cośa que sale de la natura o que non atorgan en cośa que non les viene a sus meollos, por fuerza cale que digamos por ellos que son minim y apicorosim y cafrantes en la Ley, que él que cafra en una cośa de la Ley es como si cafra en la Ley entera ${ }^{31}$.

Papo thus shares with the «Westernizers» a vision of profound change and of progress of knowledge. For the latter, however, the growth of (non-traditional) knowledge signifies an intellectual progress which permits loosening the ties with tradition and chal-

${ }^{31} P Y$ 2:165f: "[...] there are some people whose evil impulse leads them astray and tells them that the sciences have multiplied in our times more than in ancient generations and that everyone should strive to understand and to know things by his own intellect and not with [the help of] others' intellect. And furthermore, it appears to them that our perfection should be to copy the gentiles, to imitate them in everything, even if we therefore substract something from the Law and how much more so if it is a rabbinic [ordinance]. And furthermore, they base their thought [on the assumption] that there is nothing beyond [the laws of] nature and they do not give credit to everything that is beyond intellect and nature. They have this from reading books of philosophers, for in their mind there is nothing beyond nature. According to everything we have said and what has been explained well, the Law and the commandments proceed from a very elevated and holy place above [the laws of] nature, for there are so many things in the Law that are against [our] intellect and [the laws of] nature and we Jews are nonetheless obliged to obey them. And those who [assume] in their intellect that there is nothing which goes beyond nature or who do not obey anything which does not proceed from their own intellect, we must definitely say that they are heretics and epicureans and sinners against the Law. Because he who rebels against one aspect of the Law is like someone rebelling against the entire Law'. 
lenging the rabbinic authority ${ }^{32}$. They call for an individualization of knowledge, allowing the individual Jew to define his or her personal stand with regard to the traditional heritage -even to the point of questioning its basic assumptions.

For Papo, this predictably amounts to questioning the entire rabbinic universe tout court. In the passage on the impact of steam ships and telegraphs we have seen, however, that for him something else is at stake. While defending tradition, he affirms and praises change, and it might indeed finally lead to redemption, if only the Jews remain faithful to their Law at this critical point of God's history with His people.

\section{The Spiritual Telegraph: A Vision of Progress}

Let us turn now to take a look at how Yeuda Papo argues his case for the importance of the Law and the commandments. He carries his argument against the «Epicureans» further, namely that the Law is beyond what human intellect can grasp, and contrasts the «spiritual» (or holy, for that matter) with everything mundane or material and associates human intellect with the material ${ }^{33}$. Then, he again employs the metaphor of the telegraph which, according to his understanding, is a material symbol of what takes place on the spiritual plane:

En esto que diǰmos que de la Ley y de las miŝvot se haćen secretos grandes en los mundos de ariba, se quiere entendido cómo en el punto que se haće la miŝvá o que se melda en la Ley o que se diće la tefilá, cómo en aquel punto alcanza la obra suya en los mundos altos que es cuántos miles de años de camino.

\footnotetext{
${ }^{32}$ See in this context the remarks in $P Y 1: 75-77$, defining who is considered an «Epicurean».

${ }^{33}$ Which is nothing short of inverting the view of philosphical musar as in Bahya Ibn Paquda's Hovot ha-levavot, a «classic» of ethical literature. Bahya distinguishes «physical commandments» from the «duties of the heart», the former including prayer, fasting, charity, study of Tora, phylacteries, etc., while the latter ones, more important, amount to true knowledge of God which can be achieved through «reason», assisted by Scripture and rabbinic tradition. Bahya Ibn Paquda, Hovot ha-levavot, introduction (ed. Vilna 1913, pp. 9-41); originally written in 11th century Spain and first published in Hebrew 1490 in Naples, there appeared partial or full Ladino translations by Yosef Firmón in Istanbul 1569 and Venice 1713, by Yisrael B. Hayim in Vienna 1822, and by Šelomo Uzi'el in Istanbul, 1898: Cf. ROMERO Creación p. 112.
} 
Ma la repuesta es muy barata. Que la fuerza del ruhaniyut es muy terible, más de lo que alcanza muestro meollo y afilú en el gašmiyut se ve diferencia grande de más gašmí a manco gašmí: los pies que son muy gašmiyim, en una hora no pueden caminar más que una hora de camino. El oyir que es más ruhaní, en pocos puntos se oye la voź afilú de lugar lejos de cuantas horas de camino, como cuando echan el tiro y cuando sale el trueno. La vista que es más ruhaní del oyir, se ve antes de lo que se oye y la preba es que la yoź del tiro y la yoź del trueno se oye después que se ve el relámpago y la flama del tiro, afilú que salen en un punto, ma la vista aconanta el oyir. Y todo ésto es en gašmiyut, cuánto y más en el ruhaniyut, que ya dij̄imos que la Ley y las miŝvot está la punta de ellas en muestra mano, no quiere dicho que súpito que se manea la punta de abajo, se manea y haće su obra en los mundos de ariba.

Y ya diǰimos en la letra de Gueulá que el Šy"t quiere arecercar a todas las naciones en las emunot verdaderas y va descubriendo secretos de la natura, que de ello se toma enjemplo para ${ }^{1159}$ reconocer las verdades y por arecercar el meollo a conocer la fuerza del ruhaniyut. Mos amostraron de los cielos asemejante con la ḩojmá del telegraf que es gašmí: toca la una punta del tel, arodea el mundo entero en pocas horas.

La Ley y las miŝvot son telegraf ruhaní, de suyo se entiende cuánto es su fuerza. Y este telegraf ruhaní está mentado en el pasuc que lo vido Ya acob abinu cuando se fue a Harán y durmió en el lugar del Bet hamicdáš, vido en su esfueño sulam muŝab arŝa ve-rošó maguía hašamaima: es el telegraf ruhanái ${ }^{34}$.

${ }^{34} P Y$ 2:158-159: 'Having said that from the [observance of] the Law and the commandments great miracles are caused in the upper worlds, one has to understand how in the moment of the perfomance of a commandment or the studying of the Law or saying the prayer, it reaches in this very moment the upper worlds which are thousands of years away. But the answer is very easy: The power of the spiritual [ruhaniyut] is much more terrible than what we grasp with our intellect, and even with regard to the material [gašmiyut], one observes a great distinction between more and less material: The feet, which are very material, cannot walk in one hour more than one hour's [walking] distance. Hearing is more spiritual, in a few moments one hears a sound even in a place at several hours' distance, such as a shot or a thunder. Seeing is more spiritual than hearing, one sees before hearing [something], and the evidence is that one hears the sound of a shot or of a thunder after one sees the lightening or the fire, even though they are produced at the same moment, but seeing comes before hearing. And all this is with regard to the material. How much more so with regard to the spiritual, and we already said that [in the case of] the Law and the commandments, one end is in our hands and it goes without saying that when one moves the lower end, it moves instantly and causes its effect in the upper worlds. We already said in the chapter on 
Papo presents here another audacious re-reading of the relation of time and space. His fascination with a diminishing distance of time and space parallels a more widespread sense of simultaneity current at the time ${ }^{35}$ and is translated into the traditional universe. The growing «disembedment» of the time-space relation is analogous with a growing spiritualization, an interpretation which allows him to see modernization as a religiously positive phenomenon, though dangerous for those who let themselves be misguided into assimilation. In reality, however, the experience of simultaneity as made possible by the telegraph should be understood as a representation of the synchronization of human and divine actions.

Papo sees the relation of God and the Jews as a dialogue. He assures his reader that study of the Law and observance of the divine commandments have an immediate effect on the upper worlds and on divine actions - of course a well-known kabbalistic reading of the mitsvot. This view is, then, the basis for Papo's optimistic evaluation of redemption being possible. In this passage, again, he speaks of the rapprochement of the different nations and religions towards Jewish monotheism and even claims that the telegraph is nothing less than a divine instrument serving as an illustration of such a spiritual development.

"redemption" that God wants to lead all the gentiles closer to the true beliefs and $\mathrm{He}$ is revealing the secrets of nature, which serve as an example in order to recognize the truth and to guide the intellect to recognize the power of the spiritual. We are shown something similar from the heavens by the science of the telegraph which is material: Touching one end of the wire, it encompasses the entire world in a few hours. The Law and the commandments are the spiritual telegraph, whereby one understands how powerful it is. It is this spiritual telegraph which is mentioned in the verse [Gen 28:12], when our father Jacob, on his way to Haran and sleeping at the site of the Holy Temple, saw in his dream «a stairway set in the ground and its top reached to the sky»: This is the spiritual telegraph'.

${ }^{35}$ Stephen KERN cites many examples for the fascination with «simultaneous» experience, from comments on the telegraph through the sciences to poetry and music: "Already in 1889 Lord Salisbury commented on the simultaneity of experience made possible by the telegraph, which had "combined together almost at one moment ... the opinions of the whole intelligent world with respect to everything that is passing at that time upon the face of the globe"” (KERN Time and Space p. 67). In 1913, Blaise CEndRARs published her La Prose du Transsibérien et de la Petite Jehanne de France as the «First Simultaneous Book» (KERN Time and Space pp. 72f). Only with Einstein would this sense of «simultaneity» become untenable (KERN Time and Space p. 81). 
What, then, are the concrete developments which motivate Papo's optimism? At one point, Yeuda insists that his own times do in fact merit seeing the redemption of the Jews and the restoration to their homeland, with the condition that they observe the commandments and engage in repentance (tešuva). Among the factors he cites in support of his optimism, he includes in the first place innovations made during his time which make man's life «more tranquil» and "more secure». He then repeats his argument of the gentiles having taken over ideals of Judaism.

Significantly, additional factor is the publication of the Pele Yo ets itself which would contribute to make rabbinic knowledge available to everyone so that ignorance of tradition is remedied. The progress in the Ottoman printing industry in general would cause a spread of rabbinic literature. Finally, the activities of the Alliance Israélite are a positive factor, though it should advance the respect for and knowledge of religious tradition rather than propagating Western ideas ${ }^{36}$.

All these factors -new modes of communication, scientific progress, and the author's own book- are merged into an image of a dawning new age of an accelerated movement towards a bright future. This age is characterized by the religious assimilation of other peoples to the ideals of Judaism (and not the other way around) and might indeed lead to redemption. Redemption, to be sure, is understood in "national» or "political» terms as the reestablishment of Jewish sovereignity in Palestine. All this amounts to a post-traditional mode of perceiving change and of understanding future.

Niklas Luhmann has differentiated between traditional and modern societies by arguing that there exists a relation between the increasing differentiation of social systems and an increasing dissociation of past and future. Modern societies are characterized by «futurization» ${ }^{37}$, i. e., an increasingly open future. The term «open» has to be qualified: It means first of all that it is not preordained by a mythical, idealized past or past, idealizing revelations. "Open» means that a whole range of options (though not everything) becomes a possibility of selection. Future is a

\footnotetext{
${ }^{36}$ Papo describes these developments in PY 2:199-204.

${ }^{37}$ LuHMANN «The Future» p. 141.
} 
horizon which is never reached or, as Luhmann says, it «cannot begin», because every selection, every realization of a future possibility leads to another range of future options.

In order to avoid misunderstandings, one has to point out some paradoxes, however. While in modern societies past and future become part of the same chronology and one causal line of historical development and traditional societies sometimes appear to have lived in an endless present ${ }^{38}$, the dissociation of past and future has made very distant pasts and futures quite irrelevant to the present in modern societies ${ }^{39}$, while the representations of precisely such distant (mythic) past and distant (utopic) future has determined much of the parameters of traditional presents.

With regard to «futurization», modern societies certainly did not only perceive the future as increasingly open but at the same time believed it possible and tried to control this openness. One has only to think of the defuturizing effects of statistic calculus with the growing interest in statistics in the seventeenth and eighteenth centuries ${ }^{40}$. When we think of the Enlightenment or (early) nineteenth century optimism, moreover, though the future is open, there is still a strong sense of having arrived, as it were, at the future point of human evolution, being understood as bourgeois society ${ }^{41}$.

How modern is Yeuda Papo's understanding of future? I propose to see here an example of transforming traditional conceptions of time, preserving certain elements of it while introducing new ideas as well. He significantly transforms the traditional view of a present which derived its meaning from the relation to an ahistorical past and a utopian future when the present will return to the golden age of mythical past. For Papo, the future becomes an «open» future in the sense of a range of possibilities, one step

\footnotetext{
${ }^{38}$ This must not be understood as if traditional societies did not experience any change -but change and innovation were not, unlike in modern times, seen as something positive to be pursued. Rather, like in Rodeti's case which we shall see below, traditional authors tend to construct a fiction of endless continuity, interpreting change away.

${ }^{39}$ LuHMaNN «The Future» p. 136.

${ }^{40}$ LUHMANN «The Future» p. 141.

${ }^{41}$ Cf. Reinhart KoselLeCK, "Vergangene Zukunft der frühen Neuzeit», in KOSELLECK Vergangene Zukunft pp. 17-37.
} 
emerging out of the next, not being predetermined and being continuous with the present, not interrupting historical time by divine intervention from «outside». God's acts do, indeed, correspond to human actions and thus are taken, by the simile of the «spiritual telegraph», into the time of present human existence.

The future, the beginnings of which Yeuda sees in his contemporary world, is an open possibility and it is inscribed in historical processes. The topics are the traditional ones -namely, restoration of the Jews to their homeland- but this restoration will be achieved by political action of other peoples. Furthermore, Papo explains,

[...] que puede ser que será como la sebará de Šemuel, que su sebará es que non habrá ninguna diferencia de muestro tiempo al tiempo del mašíah otro que los j̧idiós non estaremos debajo del comando de las naciones ${ }^{42}$.

For Papo, there will be no interruption in the flaw of time but revolutionarizing Israel's political condition. This view represents, probably being a long-term response to the crisis of Ottoman Jewry after the Sabbatean meltdown, a return to the stance of medieval Jewish rationalist thought, namely the Rambam ${ }^{43}$. It departs from the dominant, non-rationalist view as it is expressed, for example, in Khuli's Me am Lo 'ez emphasizing that redemption will not be a natural event but will be brought about by divine intervention ${ }^{44}$. The reclaiming of Maimonides the rationalist was, of course, an essential part of the haskalah project of transforming Jewish society ${ }^{45}$.

${ }^{42}$ PY 2:205: '[...] it is possible that [redemption] will be according to the opinion of Samuel for according to his opinion there will be no difference between our times and the times of the Messiah other than that we Jews will cease to be under the command of the gentiles'.

${ }^{43}$ Papo refers to BT-Berakhot 34b and BT-Sanhedrin 91b, which are taken by Maimonides as evidence for redemption as an event within the natural course of things: Mišne Tora, book I, Hilkhot Těsuva, 9, 2 and book XIV, Melakhim uMilhamotehem, 12, 2. Both passages appear in Isadore TwERSKY, A Maimonides Reader (New York 1972) pp. 83 and 224.

${ }^{44}$ Jacob Khuli, Me'am Lo'ez Berešit, «Lekh lekha», ch. 4 (ed. Izmir 1864, p. 105b): «... que sepa que la gueulá es reǵida de los cielos y no pense que es algún micré» (I quote according to the edition printed by the same Rodeti whose Sefer $K i \mathrm{Ze}$ Kol ha-Adam we will discuss below).

${ }^{45}$ Mordechai BreUER, «Frühe Neuzeit und Beginn der Moderne», in DeutschJüdische Geschichte in der Neuzeit, vol. I: Tradition und Aufklärung, 1600-1780, ed. Mordechai Breuer and Michael GraEtz (Munich 1996) pp. 85-247: p. 225. 
This modern understanding of future allows Papo to perceive change as a fact and to ascribe it a positive function in the drama of religious history. Papo believes, in his manner, in progress:

[...] que afilú que a la parencia parece que cuando non se hiźo la tešubá y ma asim tobim en tiempo avante, cuánto y más que non se viene a haćer en este tiempo. Y la verdad non es ansí, que muy cercano y colay es en este tiempo de haćermos buenos jidiós ${ }^{46}$.

Technological innovation and change mean the rapprochement of religions on a «spiritual» level and might lead to political actions in favour of the Jews. The movement towards this point is one of progress. Papo therefore does not decry his own time, as was usually the case in ethical rabbinic literature throughout the ages, as one of decline and moral decay -again exemplified in Khuli's Me am Lo'ez, where he states that «también que el sadic que nace no puede ser tan sabio cuanto el primero, siendo vemos que el mundo va discrepando y la diferencia es muncha en cada tiempo de un dor a otro» ${ }^{47}$. For Papo, in contrast, modern times have led the Jews closer to redemption, not farther away.

There have always been, of course, acute messianic expectations in Jewish history. Papo however, notwithstanding his optimism and belief in progress, still sees the eventual developments as open and far from predetermined. He maintains that whatever one might expect from the future is necessarily conjectural and -in contrast to others' messianic speculations- he insists that even the interpretation of the Biblical verses with reference to redemption can never be certain ${ }^{48}$. He presents a distinct and, I argue, «modern» vision of the messianic future as a future point of a continuous chronological and progressive development, his own time worthy of seeing redemption.

To sum up, the revolution of communication networks in the nineteenth century Ottoman Empire causes Yeuda Papo to articulate a new vision of a present future. Mundane and divine

\footnotetext{
${ }^{46}$ PY 2:199: '[...] even though it might appear that, if there has been no repentance and good deeds in earlier times, how much more so they cannot be expected in the present time. But in reality it is not like this, the time being near and appropriate to make of us good Jews'.

${ }^{47}$ Me'am Lo'ez Berešit, «Haye Sara», ch. 1 (ed. Izmir 1864, p. 154a): ‘... the righteous who is born cannot be as wise as the other [who passed away], as we see that the world is constantly regressing and the difference between one generation and another is significant'.

${ }^{48}$ PY 2:205.
} 
processes being perfectly synchronized, the phenomenon of temporal-spacial coming closer is interpreted as «actually» conveying the sense of a «spiritual» rapprochement between cultures. Modern changes are progress and lead towards an open but promising future.

\section{Nothing New Under the Sun: Hezekiah AND the TELEGRAPH}

A very different reference to the technique of the telegraph is found in Binyamin Ben-Tsion Rodeti's Sefer Ki Ze Kol ha-Adam. The second part of the book deals with the issues of illness and death. In one paragraph, Rodeti discusses in much detail the illness and cure of king Hezekiah as described in Is 38:1-39:8 ${ }^{49}$. The main issue of the text is the power of prayer in the hour of illness and threat of death. When Hezekiah's prayer is heard and he is promised recovery, he asks for a divine sign proving that this is really true. The answer he is given, «and this is the sign for you from the Lord that the Lord will do what He has promised: I am going to make the shadow on the steps, which has descended on the dial of Ahaz because of the sun, recede ten steps ...» (Is 38:78 ), prompts Rodeti to cite the midrashic commentary on the episode of Babylonian king Merodakh's message to Hezekiah ${ }^{50}$ :

[A] Merodaj ben Baladán estaba uśado a comer a las 6 horas de el día y durmía hasta las 9. [B] Siendo que oyó el Šy"t la tefilá de Hiiźquiyá y le respondió que le pujó 15 años, en aquea hora demandó Hiźquiyahu señal del Šy " $t$ cómo es verdad que le pujó 15 años. Y tenía que subir al B[et] hami"c[daš]. Le respondió el Šy"t: «Veźé lejá haot ('esta es la señal'). Que te vo avoltar el sol atrás dieź escalones» ${ }^{51}$, que en aquea hora era las dieź de el día y el sol está de parte de ma'arab, y yoltó el galgal de el sol a la

\footnotetext{
${ }^{49} K A 4 \mathrm{~b}-7 \mathrm{a}$.

${ }^{50}$ Rodeti translates from Yalqut Šim oni, II Kings 20, 244. Cf. also Pesiqta deRav Kahana II.6; Šir ha-širim Rabba III.4.2; Zohar II.174b-175a; BT-Sanhedrin 96a; Louis GinzBERG, The Legends of the Jews (7 vols., Philadelphia 19475) vol. 4, pp. 275f, and 300 . In the transcription, I divide the paragraphs as [A] through [E] in order to facilitate subsequent references.

${ }^{51}$ I.e., the shadow on the sun dial of Ahaz: cf. Is 38:8. The Soncino translation of the Talmud explains: «The return of the ten degrees is assumed to mean a prolongation of the day by ten hours, light having healing powers».
} 
parte de miźrah y parecía que era demañana y se hiźo el día dieź horas más grande. El sol que se había hundido el día que murió Ahaź, que se escureció el día ${ }^{7 a}$ dieź horas para que no lo endecharán, agora se le aclaró a Hiźquiyá su hijo (Raš"í, Yeša iá $\left.38^{52}\right)$.

[C] En este día de el nes de Hiźquiyá que se echó a durmir Baladán como su uśanza de cada día, y se despertó vido que estaba el sol de parte de miźrah, se le asemejó que durmió hasta el otro día demañana, y bušcó a matar a sus esclavos cómo lo dejaron durmir este carar el día con la noche. Le respondieron los esclavos: «Muestro señor el rey, el día es que se alargó, que se voltó a el charc de la mañana y este nes le hiźo el Šy" t a Hiźquiyahu que lo melećinó de la haćinura que estaba». Dijo el rey: «Un hombre como este estimado ¿y no le mando šalom?». Le escribió una carta este nósah: «Šalom a el rey Hiźquiyahu, šalom a la civdad de Yerušaláyim, šalom a el Dio grande».

[D] Nebujadneŝar era el escribano de el rey, no se topó ahí cuando escribieron esta carta. Cuando vino les demandó: «¿Qué modo escribiteš la carta?». Le respondieron asegún la copia dita. Les dijo a ellos: «Lo llamateš Dio grande jy acolantáš a escribirle šalom a el esclavo antes de el amo! En primero calía que escribieraš "šalom a el Dio grande" y "šalom a Yerušaláyim" y "šalom a Hiźquiyahu"». Le diǰeron a él: «Muy bien dijites; va volta al coreo y escribe asegún queres». En lo que caminó 3 pasos, vino Gabriel y lo detuvo a el coreo para que no caminara más Nebujadneŝar. Y dijo rabí Yohanan que si no lo detenía Gabriel, no tenían tecumá h[as]" ve[šalom] Yisrael, que por el sajar que caminó 3 pasos le diǰo el Šy"t: "Tú caminateš 3 pasos por mi kabod; ihayeja!, que yo quito de ti 3 reis grandes que podesten de un cabo de mundo hasta otro y estos son Nebujadneŝar y Evil-Merodaj y Belšaẑar». Diǰo el Šy"t: «Umá por sajar de tres pasos que corió, tú tienes maravía que le paguí este carar, cuando yo pago el sajar a Abraham, Yishhac y Ya'acob, que corieron delantre de mí como el caballo, 'a[l] a[hát] k[amá] "v[ejamá]». Hasta aquí es su lašón.

[E] Que de este cuento de Merodaj se puede prebar que el telegraf ya estaba en el mundo -en kol hadáš-, siendo que Hiźquiyá era en Yerušaláyim y Merodaj en Babel, que tiene cuántos conaques

${ }^{52}$ Rashi on $I s 38.1$. 
en camino, y lo supo en aquea hora asegún dijo el pasuc: $B a$ et hahí šalah Merodaj vejú' [Is 39:1] ${ }^{53}$.

This brief passage allows us to observe several aspects which would seem to be central to Rodeti's outlook on time and his literary strategies which, in turn, are indicative of modern JudeoSpanish rabbinical literature's use of the classical rabbinic sources. He translates the midrashic passage from the Yalqut quite literally

${ }^{53} K A$ 6b-7a: 'Merodakh ben Baladan used to eat at the 6th hour of the day and sleep till the 9th [hour]. When God heard Hezekiah's prayer and answered him that he would grant him [another] 15 years, at that hour Hezekiah asked for a sign from God, that it is true that he would grant him [another] 15 years. He had to go up to the Holy Temple. God answered him: «This shall be the sign. I will turn the sun back by ten degrees", since at this hour it was the 10 th [hour] and the sun stood in the West and He returned the sun to the East and it appeared as if it were [still] morning and the day was prolonged by ten hours. For the sun had been hidden on the day on which Ahaz died and the day darkened during ten hours lest they mourn him, now it was brightened for Hezekiah, his son. The day of the miracle of Hezekiah['s recovery], Baladan went to sleep as he used to every day and when he woke up, he saw that the sun stood in the East and thought that he had slept till the next day's morning and wanted to have his servants executed because they let him sleep so much, day and night. The servants answered him: "Our lord, the king, the day was prolonged and the sun was returned to the morning [hour], and God did this miracle for Hezekiah whom he cured from his illness". The king exclaimed: "A man so esteemed as [Hezekiah], and I do not send him regards?» [So] he wrote him [Hezekiah] a letter as follows: «Peace upon king Hezekiah, peace upon the city of Jerusalem, peace upon the great God». Nebuchadnezzar was the king's scribe [but] was not there when they wrote the letter. When he came, he asked them: «How did you write the letter?» They answered him as has been cited. He said to them: "You call Him "the great God" and have sent greetings to the servant [the king] before the lord [God]? You should have written first "peace upon the great God" and [then] "peace upon Jerusalem" and "peace upon Hezekiah"». They told him: "Very well have you spoken; go call the messenger back and write as you suggest». When he had taken three steps, Gabriel came and stopped the messenger in order that Nebuchadnezzar should not go any further. Rabbi Yohanan said that, if Gabriel had not stopped him, Israel could not have been saved, for by virtue of the three steps he had taken, God told him: «You walked three steps for my honour, I surely will grant you three great kings from your offspring who will reign from one end of the world to the other, and they are Nebuchadnezzar, Evil-Merodakh, and Belshazzar». God said: «If you wonder how I have paid him so much for the virtue of the three steps he ran, how much more so when I pay the virtue of Abraham, Isaac, and Jacob who run before me like a horse" [Till here is the quotation from the Yalqut]. From this story about Merodakh it can be proven that the telegraph was already in existence; there is nothing new: Hezekiah was in Jerusalem and Merodakh in Babylonia, and there are so many palaces on the way [in between], but he knew at this very hour [about Hezekiah's recovery], as the verse says: At this time [ba-'et ha-hi, Is 39:1] sent Merodakh etc.'. 
$(\mathbf{A}, \mathbf{C}$ and $\mathbf{D})$ and clearly indicates where the translation ends and what is his commentary (E). Though he inserts an explicatory paragraph (B), he does not introduce his remark that «the telegraph was already in existence» where it would have fitted $-\mathrm{i}$. e., at the end of paragraph (C) and before introducing the second story about the wording of Merodakh's letter to Hezekiah (D)but prefers to respect the original passage in its entirety and only then feels free to add his own remark.

Though added at the end, however, Rodeti's own commentary is meant to actually close the story and add a new perspective, which he achieves by finishing it with the reference phrase from the biblical text which opens the passage in the original text as given in the Yalqut. His brief remark, to be sure, gives the story an entirely new and surprising point which significantly contrasts with the telegraph as a metaphor as it had been used in the Pele Yo'ets.

Rodeti's is a fine example of the use of traditional sources in modern Judeo-Spanish rabbinic literature. His book continues the «anthological imagination» ${ }^{54}$ of the rabbinic textual tradition and, more specifically, continues the example of the Judeo-Spanish «classic», the Me'am Lo'ez. The collection and translation into Judeo-Spanish served its authors-compilators to transform and remould the original texts they wanted to present to a broad, JudeoSpanish speaking public. As Louis Landau has shown for the case of Khuli's Me 'am Lo ' $\mathrm{z} z$ on Genesis, the work could not be farther from being a simple «collection» of rabbinic source texts as its author claims in his introduction. Indeed, he quite freely introduces changes in the wording and structure of his sources ${ }^{55}$.

Rodeti, however, seems more scrupulous in his treatment of the original text. He is audacious enough to give the text an entirely new turn by skillfully associating it with a contemporary issue, but he does not interrupt the narrative flow of the original text and adds his commentary, neatly marked as such, only after having

\footnotetext{
${ }_{54}$ David STERN, «Introduction: The Anthological Imagination in Jewish Literature», Prooftexts 17 (1997) (= The Anthological Imagination in Jewish Literature, part 1) pp. 1-7.

${ }^{55}$ Louis LANDAU, «Ha-transformatsya šel ha-sipur ha-talmudi ba-"Me'am Lo'ez"», Pe 'amim 7 (1981) pp. 35-49; and «Me'am Lo'ez: Masoret ve-hidušah basifrut ha-sefaradit-yehudit», Sevet va- 'Am (N.S.) 5 (1984) pp. 307-32T.
} 
given an accurate (though not necessarily «literal») translation of the passage from the Yalqut Šm ioni. He believes that tradition can speak for itself and has eternally valid answers without needing to be reworked by him as compilator and translator.

The fact that Rodeti introduces his reference to the telegraph at this point is no coincidence, of course. The text from Isaiah itself (and its midrashic commentary cited by Rodeti) plays on different representations of time which is always dominated by God and never independent of divine will. Thus it is God who allots fifteen more years of life to Hezekiah; it is God who miraculously makes the sun regress by ten degrees thus making the day longer; and earlier, when Sennacherib beleaguered Jerusalem, God had prolonged darkness and an angel killed Israel's enemies (Is 37:36).

Paragraph (D) of the midrashic account translated by Rodeti furthermore is evidence of how he understands history: Power and powerlessness of Israel and the other nations (here, the Babylonian kings) are determined by God. In political history, the dynamics of reward and punishment are played out on a collective level, just as illness is explained in the frame of reward and punishment in an individual sense.

This divine command over time is reaffirmed by Rodeti in the face of modern changes in the time-space relation. Technological innovation thus should not be misunderstood as challenging the divine control of time and therefore of human experience. Scientific progress does not switch the biblical patterns of God directing and allotting time.

How is the reference to the telegraph inscribed in Rodeti's exposition? Firstly, in the chapter dealing with illness and death, the issue is about personal experiences of time. New patterns of time brought about by technological or cultural change do not, for Rodeti, have any implications for the individual experiencing time; just as the world, so the individual is subject to the divine control over time. Moreover, the chapter is about prayer. As has been seen in Papo's talk of the «spiritual telegraph», prayer as communication with God likewise could be linked, by the way of metaphor, to the communication revolution of their own time. Again, modern times do not change at all the ways man communicates with God in prayer. 
To Rodeti, all that is relevant to human existence has already been said; all that is necessary to understand has already been explained. Actually, whatever seems like change has really always existed. Rodeti's attitude thus conforms with medieval Jewish historiography among the characteristics of which Yosef Hayim Yerushalmi has numberd its "[r]esistance to novelty in history» and tries to fit present events into the mold of past «precedents» ${ }^{56}$. «For the rabbis», Yerushalmi held, «the Bible was not only a repository of past history, but a revealed pattern of the whole of history» ${ }^{57}$.

Rodeti applies this attitude towards history to the situation of technological innovation. He insists that the telegraph was in existence in the times of Hezekiah -quite a remarkable supposition, the objective of which is to defy any possible inference of internal changes within the religious universe from outward, technological change. Rodeti thus takes up a position contrary to Papo: While both defend tradition against the challenges of modernity, Rodeti does not accept the very notion of change and argues that tradition has valid answers because everything is already anticipated in tradition. Papo, for his part, accepts the fact of change but reinterprets it as leading towards redemption in an optimistic vision of a progressively victorious tradition.

\section{Two Perspectives on the Present}

Yeuda Papo's Pele Yo ets partakes, as it were, in a broader discourse on time which could be observed throughout at least the Western world in the decades around the turn of the century: «[T]he wireless and telephone, ... simultaneity and the spatially expanded present, ... the temporally thickened "spacious present", and finally ... the positive evaluation of the present ... outline the distinctive experience of the present in this period ${ }^{58}$,. It would be out of place to construct Papo as a decidedly modern or «progressive» author. But if we see the dissociation of past and present, experience and expectation as constitutive of modern culture, Papo's book represents important semantic changes in its evaluation

56 YeRUSHALMI Zakhor p. 51.

57 YeRUSHALMI Zakhor p. 21.

${ }^{58}$ KERN Time and Space p. 87. 
of the present which comes to be seen as being inscribed in a history of progress. He expresses the expectation of the Jews' redemption in historical time and reaches out to a present future, a future which is open and historical but not deferred to the traditional, non-present future of the world-to-come or messianic redemption.

Whoever is familiar with modern Jewish history will recall another Sephardic rabbi writing at the same time as the young Papo: Yehuda Alkala'i from Bosnia who had actually been studying with Eli'ezer Papo, author of the Hebrew Pele Yo'ets. When he published his booklet Šema' Yisrael in 1834, he proposed the creation of Jewish colonies in the Holy Land in order to actively advance redemption.

On the basis of kabbalistic speculations, Alkala'i was convinced that the year $5600(1839 / 40)$ would be the year of the Jewse redemption or ${ }^{59}$, the year having passed without restoration to the Land of Israel, at least a decisive moment in the transition toward the final redemption. Fuelled by the upheavals of the 1840 Damascus «blood libel» and the diplomatic efforts of West European Jews (the mission of Crémieux and Montefiore to the Middle East) ${ }^{60}$, Alkala i propagated his program of «self-redemption», his reinterpretation of the ancient concept of tešuva ('repentance') in its literal sense of 'return' -return of the Jews to the Holy Land and its colonization ${ }^{61}$.

Mark D. Angel has compared the activism of Yehuda Alkala i with Eli'ezer Papo's quietist and passive attitude to modernity as represented in the Hebrew Pele Yo ets ${ }^{62}$. It certainly appears that the Ladino version of the Pele Yo ets engages in a subtle never explicit polemic against Alkala i's activist approach. Yeuda Papo clearly argues that the return of the Jews to their homeland must

\footnotetext{
${ }^{59}$ Alkala $i$ was not alone with his «messianic» expectations for the year 1840: Cf. Arie MORGENSTERN, «Tsipiyot mešihiyot liqrat šenat $5600(1840) »$, in Mešihiyut ve-eskatologia, ed. Tsvi BARAS (Jerusalem 1983) pp. 343-364.

${ }^{60}$ Jonathan Frankel, The Damascus Affair: «Ritual Murder,»Politics, and the Jews in 1840 (Cambridge 1997).

${ }^{61}$ Norman STILlman, «"My Heart's in the East" -Sephardi Zionism», in Norman Stillman, Sephardi Religious Responses to Modernity (Luxembourg 1995) pp. 49-64; Arthur HerzBerg (ed.), The Zionist Idea (New York 1960) pp. 103-107.

${ }^{62}$ Mark D. Angel, Voices in Exile: A Study in Sephardic Intellectual History (Hoboken - New York 1991) pp. 135-143.
} 
be the result of external political developments and refutes the calculation of the messianic end of historic time ${ }^{63}$. Alkala $i$ and Papo share, however, the awareness of change and a reevaluation of the present. Both represent a view of present and future being part of a progressive history moving toward national redemption in historical time. Theirs is a «present-oriented view of the future».

Papo's and Alakalai's view contrast with a second trend in modern Judeo-Spanish rabbinic literature, represented here by Ben-Tsion Rodeti. His vision is probably summed up well in a story he tells in his Sefer Ki Ze Kol ha-Adam, though there is no explicit reference to the troubled times of modern change but rather to the troubled times of individual illness: There is a ship caught in a terrible storm on the open sea. The passengers throw the ballast into the water and try to save the ship from sinking. One of them throws his talit overboard. "Could there be a worse foolishness?», asks Rodeti: Not only that the talit does not weight much; serving for prayer, it actually would be the only way of salvation. The author then explains that in the same manner, especially in times of illness, one should be praying and reading the biblical and rabbinic texts he then includes in a Judeo-Spanish translation in his book ${ }^{64}$.

The simile could also be read as a response to the uneasy times of modern transformation: In Rodeti's view, one should certainly not throw the traditional heritage, the divine commandments, overboard. Rather, he affirms the importance of communication with God -and that everything one has to know is actually already included in the canon of traditional knowledge from biblical and rabbinic literature passages from which he then sets out to scrupulously render into Ladino. His can be described as a «pastoriented view of the future».

\section{CONCLUSIONS}

Though it is highly tenuous to establish general trends from the two isolated examples seen here ${ }^{65}$, Yeuda Papo's and Ben-Tsion

${ }^{63} P Y 1: 146$.

${ }^{64} K A$ 9b-10a.

${ }^{65}$ The conclusions are drawn from a broader research in progress on the JudeoSpanish ethical literature and I hope to expand on the points suggested here in the future. 
Rodeti's texts seem to represent two attitudes towards change in the modern age among Eastern Sephardic rabbis. Both are conservative in the sense of defending the traditional universe against challenges from without and post-traditional in the sense of their traditionalism being an ideologically motivated reaction to alternative models; rabbinic authority is not something obvious any more but has to be defended 66 .

They construe different answers to the challenges of modernity, however. While Papo embraces change as historical progress and reevalutes the present with its sweeping transformation as important -and positively so-, Rodeti prefers to read the present through the utopian past of an untouched textual tradition. Rodeti's «en kol hadaš» clearly contrasts with Papo's view of the present as harbinger of better, but still historical, times.

The observations presented here allow us to move away from the erroneous assumption that the Sephardic rabbis formed one unified block in their reaction to the forces of modernization and to understand their highly ambiguous view and multiple interpretations of modern change.

${ }^{66}$ On the difference between «traditional» and "conservative», cf. also Karl MANNHEIM, «Das konservative Denken: Soziologische Beiträge zum Werden des politisch-histor ischen Denkens in Deutschland», in Karl MANNHEIM, Wissenssoziologie, ed. Kurt H. WOLFF (Berlin-Neuwied 1964 [originally published 1927]) pp. 408-508: 412-417. 


\section{RESUMEN}

En este artículo analizo las referencias a la introducción del telégrafo en dos libros de musar del siglo XIX publicados en ladino: el Pele Yo és, cuyo versión judeoespañola preparó Yeudá Papo, y el Séfer Ki źe kol haadam, de Ben-Ŝyón Binyamín Rodeti. Los pasajes nos permiten estudiar cómo entendieron estos dos rabinos sefardíes el tiempo presente y el futuro, así como los cambios en un período de avances técnicos y transformaciones sociales como los que se produjeron en el Imperio Otomano del siglo XIX. Podemos distinguir dos tendencias. Mientras que el libro de Papo anuncia importantes transformaciones semánticas en el entendimiento del tiempo-aunque él mismo nunca sale del márgen de la tradición rabínica-, Ben-Ŝiyón Rodeti descarta que haya cambios y afirma que todo ya se ha dicho en la tradición literaria rabínica y que los tiempos actuales no cuestionan ni pueden cuestionar esta tradición.

\section{SUMMARY}

In this article, $I$ analyze the brief references to the invention of the telegraph in Yeuda Papo's Judeo-Spanish version of the Pele Yo ets and Ben Tsion Rodeti's Sefer Ki Ze Kol ha-Adam, two Judeo-Spanish books of musar from the nineteenth century. These rather unlikely references permit us to study perceptions of present, future, and change held by two Sephardic rabbis from the Ottoman Empire in a period of accelerated technological progress and social transformation. Two different attitudes towards change can be described. While Papo's work announces important transformations in the semantics of understanding time, without stepping outside rabbinic tradition itself, Ben Tsion Rodeti denies the very fact of change and affirms that everything that has to be known already is included once and for all in the rabbinic literary tradition. 